\title{
Gene Therapy for Skin Diseases
}

\author{
Emily Gorell, Ngon Nguyen, Alfred Lane, and Zurab Siprashvili \\ Department of Dermatology, Stanford School of Medicine, Palo Alto, California 94305 \\ Correspondence: zurab@stanford.edu
}

The skin possesses qualities that make it desirable for gene therapy, and studies have focused on gene therapy for multiple cutaneous diseases. Gene therapy uses a vector to introduce genetic material into cells to alter gene expression, negating a pathological process. This can be accomplished with a variety of viral vectors or nonviral administrations. Although results are promising, there are several potential pitfalls that must be addressed to improve the safety profile to make gene therapy widely available clinically.

G ene-based therapeutics are broadly defined Jas using a vector to introduce nucleic acids into cells with the intention of altering gene expression to prevent, halt, or reverse a pathological process (Kay 2011).

The skin is an attractive tissue for gene therapy for several reasons. It is an easily accessible organ associated with monogenetic diseases as well as chronic wounds, which may benefit from gene therapy approaches (Khavari et al. 2002). Although the idea of gene transfer is relatively straightforward and initial attempts showed promising results, the future of gene therapeutic trials was tempered by the subsequent development of T-cell leukemia secondary to vector insertions near the LMO2 protooncogene in patients with severe combined immunodeficiency and Wiskott-Aldrich syndrome (Cavazzana-Calvo et al. 2000; HaceinBey-Abina et al. 2002, 2008; Howe et al. 2008; Boztug et al. 2010). Although this made researchers reevaluate the initial simplicity of such an approach and focus on challenges related to insertional mutagenesis, immunogenicity, and vector stability in the host (Kay 2011), clear evidence of clinical benefits lead to increased gene therapy clinical studies, resulting in 1800 gene transfer trials around the world (Ginn et al. 2013).

\section{GENE TRANSFER TECHNIQUES}

As a superficial organ, easy to manipulate and observe, the epidermis was one of the first targets for cell isolation (Rheinwald and Green 1975), in vitro tissue engineering (Green et al. 1979; Bell et al. 1981; Burke et al. 1981), and in vivo experimental gene transfer (Williams et al. 1991). In gene therapy techniques, genetic material is usually transferred using modified vectors, either directly into a subject's epidermal tissue (in vivo), or indirectly (ex vivo) in which cells are removed from the host, subjected to genetic manipulation, then reconstituted into the subject's skin (Fig. 1).

Independent of the route used in genetic material transfer, there are two fundamentally different gene delivery systems: viral and nonvi-

Editors: Anthony E. Oro and Fiona M. Watt

Additional Perspectives on The Skin and Its Diseases available at www.perspectivesinmedicine.org

Copyright (C) 2014 Cold Spring Harbor Laboratory Press; all rights reserved; doi: 10.1101/cshperspect.a015149

Cite this article as Cold Spring Harb Perspect Med 2014;4:a015149 
E. Gorell et al.

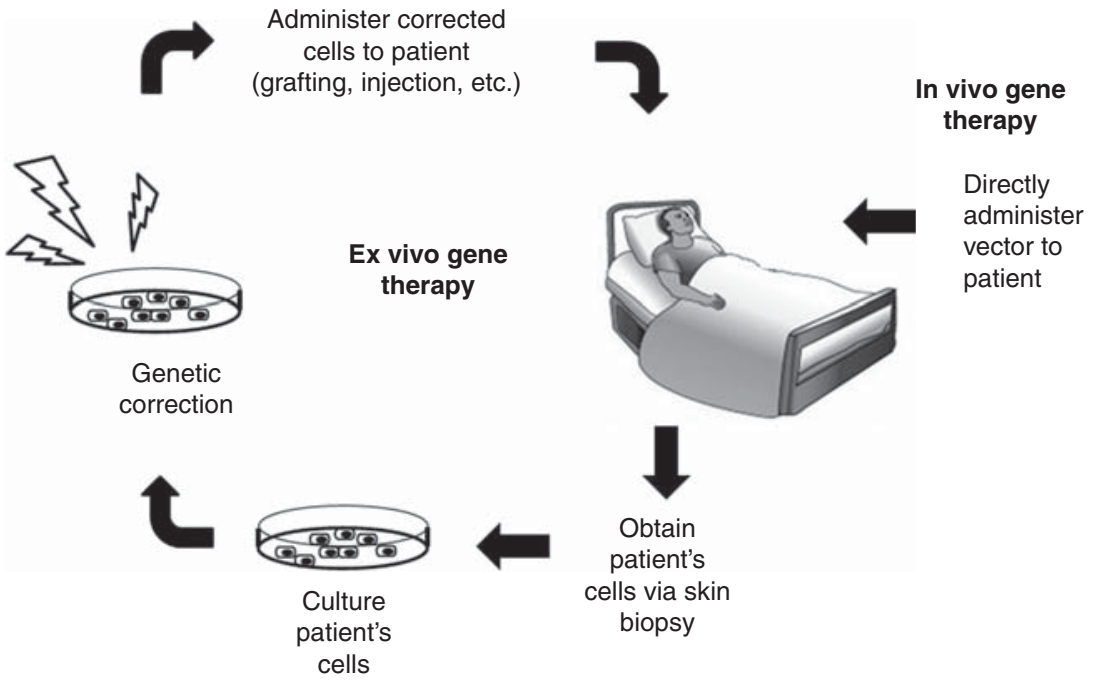

Figure 1. Gene therapy delivery methods.

ral. Either delivery system can be applied for ex vivo or in vivo correction routes.

\section{Gene Transfer with Viral Vectors}

Viral vectors are the most effective vehicles of gene transfer because of their inherent ability to efficiently infect cells (Table 1). Numerous viruses are under investigation for gene delivery, but the most commonly used viruses to target cutaneous tissue are retroviruses, adenoviruses $(\mathrm{AdV})$, and adeno-associated viruses (AAV). Although they provide superior efficacy in gene transfer, the main drawbacks are virus-associated toxicity as well as costly and complicated manufacturing.

\section{Retrovirus}

Retroviruses have the longest history of use in gene therapy and are still the most frequently used vectors for cutaneous gene transfer (Edelstein et al. 2007). Retroviral vectors use reverse transcriptase to back-transcribe their RNA into DNA and use integrase to integrate into infected host genome. They are capable of high level transduction efficiency in culture (nearly $100 \%$ ) and providing a coding capacity of $8-9 \mathrm{~kb}$.

Vectors derived from oncoviral and lentiviral retroviruses are commonly used in gene therapy. The best example of an oncoretrovirus is the Moloney murine leukemia virus (MMLV), whereas lentiviruses originate from human immunodeficiency virus (HIV). HIVbased viruses have a pronounced advantage over oncoretroviruses, namely the ability to infect nondividing cells owing to their ability to deliver the viral preintegration complex (PIC) across the nuclear membrane. Because epidermal stem cell populations have a low rate of mitotic activity, lentiviral vectors are more attractive for in vivo therapy.

On the other hand, oncoretroviruses are efficient for ex vivo gene delivery allowing transduction of epidermal stem cells, which is essential for long-term transgene expression in reconstituted skin tissue. Both oncoretroviruses and lentivectors delivered ex vivo provide the capacity for therapeutic gene expression in skin regenerated from transduced keratinocytes (KC) for several epidermal turnover cycles proving successful targeting of epidermal progenitor cells (Chen et al. 2002; Larcher et al. 2007; Siprashvili et al. 2010).

General design of retroviral vectors minimizes the potential to form a replication competent retrovirus (RCR). Vector construction should retain several elements that are important for the viral life cycle, such as RNA pack- 
Table 1. Gene delivery vector characterization

\begin{tabular}{|c|c|c|c|}
\hline Gene vector & Advantages & Disadvantages & Therapeutic use \\
\hline $\begin{array}{l}\text { Retrovirus } \\
\qquad \text { (oncoretrovirus) }\end{array}$ & $\begin{array}{l}\text { High transduction efficiency in vitro } \\
\text { Sustained gene expression } \\
\text { Acceptable coding capacity of }<9 \mathrm{~kb} \\
\text { No immunogenicity }\end{array}$ & $\begin{array}{l}\text { Risk of insertional } \\
\quad \text { mutagenesis } \\
\text { Potential for silencing } \\
\text { High production costs } \\
\text { Does not transduce } \\
\text { nondividing cells } \\
\text { Prone for recombination }\end{array}$ & $\begin{array}{l}\text { Inherited genetic } \\
\text { disorders } \\
\text { Systemic diseases } \\
\text { Replacement gene } \\
\text { therapy } \\
\text { Trans-splicing RNA } \\
\text { repair }\end{array}$ \\
\hline Lentivirus & $\begin{array}{l}\text { High transduction efficiency in vitro } \\
\text { Acceptable transduction efficiency in } \\
\quad \text { vivo } \\
\text { Sustained gene expression } \\
\text { Acceptable coding capacity of }<9 \mathrm{~kb} \\
\text { No immunogenicity }\end{array}$ & $\begin{array}{l}\text { Risk of insertional } \\
\quad \text { mutagenesis } \\
\text { Potential for silencing } \\
\text { High production costs } \\
\text { Prone to recombination }\end{array}$ & $\begin{array}{l}\text { Inherited genetic } \\
\text { disorders } \\
\text { Systemic diseases } \\
\text { Replacement gene } \\
\text { therapy }\end{array}$ \\
\hline Adenovirus & $\begin{array}{l}\text { High transduction efficiency in vivo } \\
\text { High coding capacity of }<38 \mathrm{~kb} \\
\text { Does not integrate into host genome } \\
\text { Stable } \\
\text { High titer }\end{array}$ & $\begin{array}{l}\text { Immunogenic } \\
\text { Transient gene expression } \\
\text { High production costs }\end{array}$ & $\begin{array}{l}\text { Antitumor therapy } \\
\text { Chronic wounds }\end{array}$ \\
\hline $\begin{array}{l}\text { Adeno-associated } \\
\quad \text { virus }\end{array}$ & $\begin{array}{l}\text { Transduction in vivo and ex vivo } \\
\text { Sustained gene expression } \\
\text { Stable } \\
\text { High titer } \\
\text { Low immunogenicity }\end{array}$ & $\begin{array}{l}\text { Low coding capacity } \\
\quad<5 \mathrm{~kb} \\
\text { Risk of insertional } \\
\text { mutagenesis } \\
\text { Immunogenic after } \\
\text { repeated administration } \\
\text { High production costs }\end{array}$ & $\begin{array}{l}\text { Inherited genetic } \\
\text { disorders } \\
\text { Systemic diseases } \\
\text { Homology-directed } \\
\text { mutation repair }\end{array}$ \\
\hline $\begin{array}{l}\text { Nonviral (plasmid } \\
\text { DNA) }\end{array}$ & $\begin{array}{l}\text { Low production costs } \\
\text { High coding capacity } \\
\text { Does not integrate into host genome } \\
\text { In vivo administration inexpensive } \\
\quad \text { and well tolerated } \\
\text { No immunogenicity } \\
\text { Stable }\end{array}$ & $\begin{array}{l}\text { Low efficiency } \\
\text { Transient expression } \\
\text { No selectivity } \\
\text { Risk of off-target genome } \\
\text { editing using TALEN, } \\
\text { CRISPR systems }\end{array}$ & $\begin{array}{l}\text { Vaccination } \\
\text { Chronic wounds } \\
\text { Antitumor therapy } \\
\text { Inherited genetic } \\
\quad \text { disorders } \\
\text { Genome editing } \\
\text { and homology- } \\
\text { directed } \\
\text { Mutation repair }\end{array}$ \\
\hline
\end{tabular}

aging signals and cis-acting viral sequences, such as $5^{\prime}$ - and $3^{\prime}$ - long terminal repeats (LTR). Other viral sequences are removed and replaced with the gene of interest. To generate the therapeutic vector, viral proteins are supplied in trans together with the transgene construct within packaging cells derived from established cell lines (Miller 1992).

Additional genetic engineering of the targeting construct is directed to create self-inactivating (SIN) vectors including generation of a fusion $5^{\prime}$ LTR promoter, to control therapeutic gene expression, and introduction of a deletion within the $\mathrm{U} 3$ region of the $3^{\prime}$ LTR. This strategy is applicable for both lentiviral and MMLV-derived vectors.

Lentiviral vectors are more complex because of accessory proteins and sequences that allow nuclear import of viral PIC. For safety reasons, lentiviral vectors are usually produced by transient transfection methods in packaging cell lines. Pseudotyping lentiviral vectors with the surface glycoprotein from vesicular stomatitis virus $G$ protein increases stability and titer, and broadens the tropism (Dull et al. 1998; Cooray et al. 2012). 
E. Gorell et al.

\section{Adenovirus (AdV)}

The most commonly used vector today is AdV, used in $23.3 \%$ of all viral gene therapy trials worldwide (Ginn et al. 2013). They can carry a larger DNA load than retroviruses, are able to achieve high transduction efficiency in a variety of cell types including nondividing cells, and produce high albeit transient levels of gene expression because of the episomal nonintegrated state of the viral genome. These double-stranded DNA viruses can be rendered replication defective by substitution of the essential E1 gene without an apparent effect on viral growth. "Gutted" helper-dependent adenovirus is generated by stripping the majority of viral proteinencoding genes leaving essentially inverted terminal repeats and the packaging sequence at the $5^{\prime}$-end of the viral genome (Dormond and $\mathrm{Ka}$ men 2011).

Expression of AdV in the skin is brief, lasting only about $2 \mathrm{wk}$ presumably attributable to lack of genomic integration and possibly delayed cytotoxic effects (Hirsch et al. 2006). Other than tissue repair, adenovirus-based immunotherapy has emerged as a potential direction, but conclusive statements on the usefulness of cutaneous therapeutic strategies will have to await further studies (de Gruijl and van de Ven 2012).

\section{Adeno-Associated Virus (AAV)}

The nonpathogenic AAV-2 subtype of adenoassociated viruses, a member of the parvovirus family, is a common gene therapy vector. It is characterized by stability of the viral capsid, low immunogenicity, the ability to transduce both dividing and nondividing cells, the potential to integrate site specifically and to achieve longterm gene expression even in vivo. AAV vectors have an insert capacity of $\sim 4.5 \mathrm{~kb}$. Proliferation depends on the presence of a helper virus such as AdV or herpes virus.

Studies have shown that cutaneous transduction using AAV is possible both ex vivo and in vivo, although strong evidence for efficacy, duration, and vector integration is lacking. For ex vivo use, one study showed up to $70 \%$ transduced $\mathrm{KC}$, whereas another showed shortlived gene expression $(<4 \mathrm{~d})$ only in immor- talized $\mathrm{KC}$, with lack of infection in primary cells (Braun-Falco et al. 1999; Gagnoux-Palacios et al. 2005). Interestingly, packaging of an $\mathrm{AAV}$ vector with capsid serotype 6 increased $\mathrm{KC}$ transduction frequency 5 logs compared with the same vector packaged with capsid serotype 2 (Petek et al. 2010). In vivo gene transfer into porcine skin has been successfully shown after intradermal injection of recombinant AAV particles, which led to transgene expression in epidermal KCs for more than $6 \mathrm{wk}$, although with diminished transgene expression and an inflammatory response after readministration attempts (Hengge and Mirmohammadsadegh 2000). Therefore, recent improvements made in $\mathrm{AAV}$ vector design and production highlights the therapeutic potential of this vector in cutaneous gene therapy.

\section{Nonviral Gene Therapy}

Nonviral gene transfer techniques possess several advantages including cost-effective production of large amounts of vector, low toxicity, low immunogenicity, and preferential safety compared with viral vectors (Table 1 ), as there is no risk of RCR. Furthermore, nonviral gene transfer is usually characterized by transient gene expression and low transfection efficiency. Short-term gene expression may be desirable for wound healing or bone regeneration. Longterm gene expression can be achieved by selecting stable clones ex vivo. Targeting loss of function mutations is achieved by introducing a plasmid DNA ( $\mathrm{pDNA}$ ) or RNA encoding the gene of interest. Conversely, for gain-of-function mutations, therapies that reduce gene expression such as RNA interference and microRNA can be used. Moreover, recent developments in engineered nucleases to create breaks in the genome following repair based on homologous recombination using exogenous donor templates makes nonviral gene therapy vectors even more desirable to target monogenic diseases (Porteus and Baltimore 2003). These breaks can be generated by several methods: zinc finger nucleases (Pabo et al. 2001), clustered regularly interspaced short palindromic repeats (CRISPR) (Mali et al. 2013; Wang et al. 2013), 
or transcription activator-like effector nucleases (TALEN) (Osborn et al. 2013).

\section{Plasmid DNA Design}

The simplest and most straightforward gene delivery vehicle is pDNA. Plasmids are propagated in bacteria, therefore they contain a bacterial replication origin and a selection marker-a gene conferring antibiotic resistance. Tissuespecific promoters, enhancers, splicing introns, and other regulatory elements of mammalian maintenance devices such as a locus control region, ensure that the therapeutic gene is adequately expressed in target human tissue. Inclusion of insulating elements on each side of the expression cassette ensure limited influence on other genes and flanking sequence with transposon elements that allow chromosomal integration of the entire transcription unit (Tolmachov 2011). To further improve the safety profile of pDNA, minicircle DNA lacking the bacterial backbone sequence, an antibiotic resistance gene, and an origin of replication were developed with greatly increased efficiency of transgene expression in vitro and in vivo (Darquet et al. 1997; Chen 2003).

\section{Plasmid DNA Administration}

The most desirable method of cutaneous DNA delivery is topical application, yet the stratum corneum (SC) prevents DNA transport across the phospholipid-rich layer. Topically applied naked pDNA in aqueous solution can reach the epidermis via hair follicles. Although the efficiency of transgene delivery with this route is low, for hepatitis B surface antigen (HBsAg), specific antibody and cellular responses were induced in the same order of magnitude as those produced by intramuscular injection of the commercially available recombinant HBsAg polypeptide vaccine (Fan et al. 1999).

Several methods were developed to cross the SC barrier, albeit more invasive than topical application. Direct injection of interleukin-8 pDNA into porcine skin resulted in DNA uptake by $\mathrm{KC}$ and the appropriate biological response of neutrophil recruitment (Hengge et al.
1995). Hypodermic needle use often causes pain and inflammation at the injection site; therefore, there is a need to develop needlefree gene delivery strategies. One of the methods that increases skin permeability is based on a ballistic pDNA projectile across the cutaneous barrier. The first account of successful needlefree pDNA delivery was reported in 1991 using a gene gun. pDNA covered gold particles $2-5 \mu \mathrm{m}$ in diameter were shot into the skin driven by helium gas without evidence of skin injury and $10 \%-20 \%$ delivery efficiency (Williams et al. 1991). Today other high-pressure flow methods are used, mainly for immunization purposes, such as liquid jet injection (Mohammed et al. 2010), which directs a pressurized liquid to make a pathway into the skin and epidermal powder immunization, which accelerates dried-powder vaccine particles into the skin at supersonic speed (Dean and Chen 2004).

The other methods of physical/mechanical gene delivery are sonoporation (ultrasoundmediated gene transfer), electroporation, and magneto-permeabilization. Sonoporation refers to transient porosities in the cell membranes induced by ultrasound (cyclic sound pressure with frequency range $>20 \mathrm{kHz}$ ) and uptake of DNA or drug microbubbles into the cells (Miller et al. 2002). Electroporation has been used for transdermal drug delivery by increasing skin permeability by applying an electric field, which surpasses the electrical capacity of the cell membrane. A combination of long, low voltage pulses is used for DNA transfer. The first successful in vivo pDNA electrotransfer was achieved in 1991 using newborn mice (Titomirov et al. 1991). To avoid unwanted electrode contact with the subject during electroporation, magnetic fields were generated using a hand-held flat magnet applicator to deliver green fluorescent protein-encoded pDNA to guinea pig skin in vivo (Kardos and Rabussay 2012). Magneto-permeabilization provides several advantages over electroporation: there is no need for invasive electrodes, it is more cost effective, and there is greater tissue penetration by the magnetic field.

Microneedles (MN) have emerged as a potential new approach for minimally invasive de- 
E. Gorell et al.

livery of epidermal gene transfer (Pearton et al. 2012). The dimensions of MN are within the micron range and consequently their penetration, on topical application, is restricted to the most superficial layers of skin (i.e., the viable epidermis and papillary dermis). Such devices are widely used for vaccination and fall into at least four design categories: hollow, solid, coated, and dissolving (Kim and Prausnitz 2011). Coated and dissolving MNs incorporate drug within the body of the needle, providing simultaneous skin puncture and delivery. Dissolving $\mathrm{MN}$ can be manufactured as biodegradable array needles with time-dependent release (Kommareddy et al. 2012).

To further enhance topical, dermal, or transdermal gene delivery efficacy, many cationic polymers have been studied both in vitro and in vivo. However, in recent years there has been a focus on nanoparticle (NP) biodegradable carrier systems (Ditto et al. 2009). NPs vary in size from 1.5 to $1000 \mathrm{~nm}$ and are readily graftable with cationic polymers, nuclear localization signals, peptides, and polyethylene glycol to provide the ability to escape endosomes, navigate to the nucleus, target the site, and evade the immune system (Raghavachari and Fahl 2002). NPs are attractive delivery vehicles for gene silencing purposes as well. Spherical nucleic acid NP conjugates (gold cores surrounded by a dense shell of highly oriented, covalently immobilized siRNA) freely penetrate almost 100\% of keratinocytes in vitro in mouse skin and human epidermis within hours after application (Zheng et al. 2012).

Ultimately, the fact that nucleic acid in either naked or formulated form displays low transfection efficiency in vivo compared with that of viral vectors limits its usefulness for gene therapy.

\section{REVERTANT MOSAICISM}

Revertant mosaicism, also called "natural gene therapy," has received attention recently in the dermatological community. Revertant mosaicism refers to the presence of two genetically heterogeneous populations of cells resulting from spontaneous genetic correction during mitosis (Almaani et al. 2010). Cutaneous revertant mosaicism manifests as areas of phenotypically normal skin unaffected by disease. In patients with the bullous genodermatoses epidermolysis bullosa (EB), revertant areas have epidermal homeostasis indistinguishable from normal skin. Cases of revertant mosaicism have been described in all subtypes of EB, encompassing several genes, with multiple mechanisms of correction (Al Aboud et al. 2003; Smith et al. 2004; De Luca et al. 2009; Almaani et al. 2010; Pasmooij et al. 2010, 2012; LaiCheong et al. 2011; Pasmooij and Jonkman 2012; van den Akker et al. 2012). Reversion has also been described as a mechanism for the phenotype observed in patients with ichthyosis with confetti, as revertant stem cells are positively selected or there is an increased rate of mitotic recombination (Choate et al. 2010).

\section{SKIN DISEASES TREATED WITH GENE TRANSFER}

\section{Epidermolysis Bullosa (EB)}

EB is a family of inherited genetic blistering skin disorders associated with gene defects affecting gene expression of the basal epidermis. Fifteen genes and 13 proteins have been characterized and are responsible for the specific subtypes of this disease (Has et al. 2012; Marinkovich 2012). Molecular alterations in a number of specific genes responsible for $\mathrm{EB}$ have been increasingly well characterized over the past 15 years (Marinkovich 1993; Uitto et al. 1994; Korge and Krieg 1996; Paller 1996; Uitto and Pulkkinen 1996; Dang and Murrell 2008). Malfunction in any of their corresponding proteins mediating epidermal adhesion results in skin fragility and blistering.

There are three main types of EB:EB simplex (EBS), junctional EB (JEB), and dystrophic EB (DEB), each affecting different levels of the epidermis (Fig. 2). EBS is most often caused by dominant mutations in the genes encoding for keratin 5 or keratin 14, and is usually a milder phenotype than the other two forms of EB, with blisters mainly on areas of major trauma. JEB is caused by recessive mutations in the genes for 


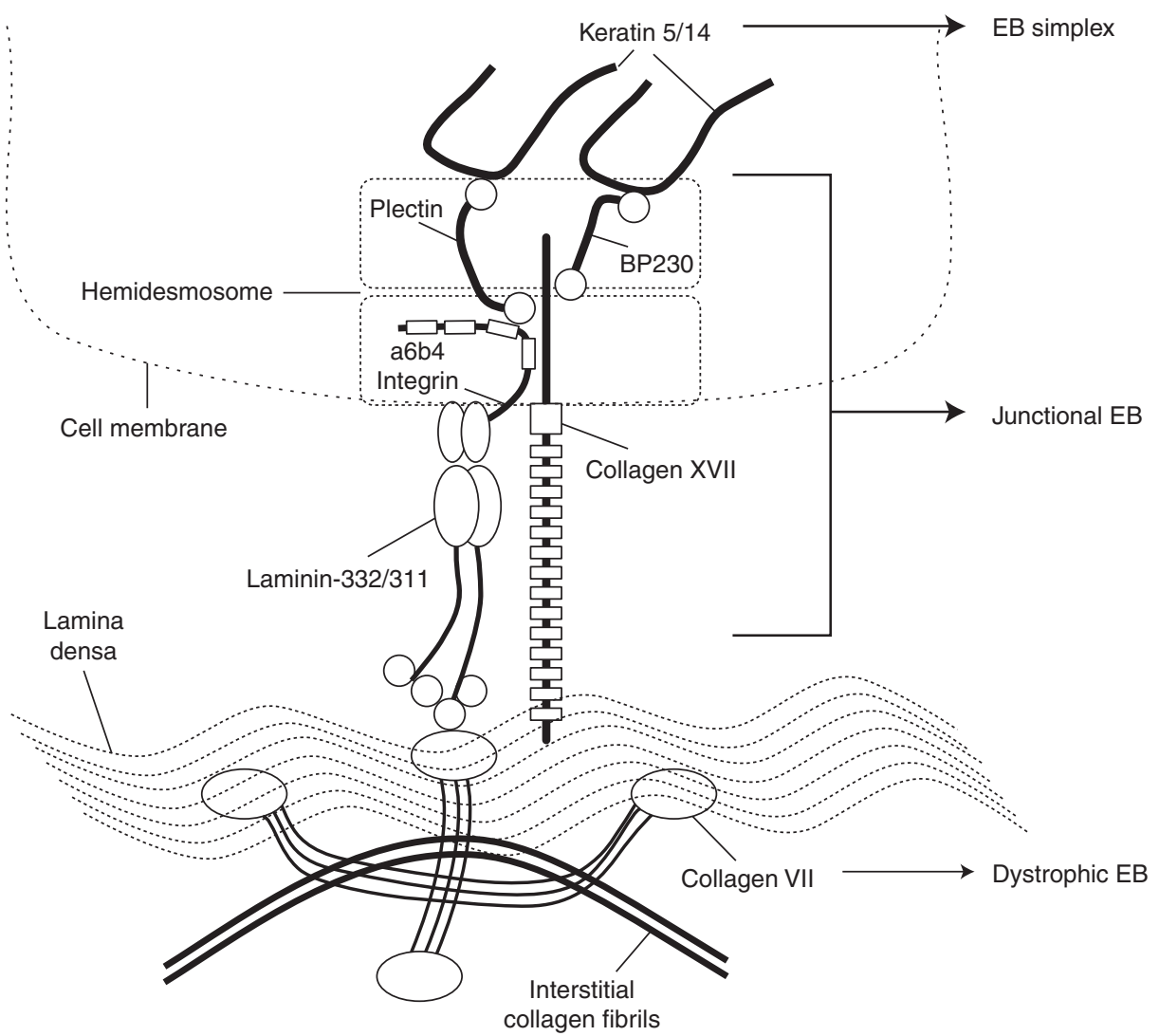

Figure 2. Proteins affected in epidermolysis bullosa. (From Marinkovich 2012; modified, with permission, from McGraw-Hill.)

collagen XVII, integrin $\alpha 6 \beta 4$, or laminin 332 . Herlitz JEB is usually lethal within the first 2 years of life. Non-Herlitz JEB is characterized by chronic skin blistering, dental anomalies, and alopecia. DEB is attributable to mutations in the gene (COL7A1) encoding type VII collagen (C7), and can be recessive (RDEB) or dominant. The more severe RDEB results in chronic blistering and scarring, esophageal strictures, mitten deformity of the hands and feet, and early death from malnutrition, sepsis, or aggressive squamous cell carcinoma (Fine et al. 2000; Uitto and Richard 2005; Marinkovich 2012).

\section{Recessive Dystrophic Epidermolysis Bullosa (RDEB)}

Many different groups throughout the world have attempted to correct RDEB. Our group has focused on RDEB gene therapy for more than 20 years, exploring nonviral methods such as the use of $\Phi C 31$ bacteriophage integrase along with a plasmid expressing COL7A $1 \mathrm{cDNA}$, to target chromosomal integration of the transgene into keratinocytes (Ortiz-Urda et al. 2002) or fibroblasts (Ortiz-Urda et al. 2003). In 2010, using a retrovirus-based therapy, RDEB KCs were corrected with COL7A1 cDNA and longterm durable expression of $\mathrm{C} 7$ seen when grafting human skin onto an immunodeficient mouse model (Siprashvili et al. 2010). A phase-1 clinical trial of ex vivo gene transfer in human subjects with RDEB using this retrovirus has been approved by the Food and Drug Administration (FDA) and is currently in progress.

Similarly, another group attempting ex vivo correction of DEB also created transplantable 
E. Gorell et al.

autologous skin equivalents using a retroviral vector to transduce C7 into primary human KCs, which they grafted onto immunocompromised mice. These grafts showed characteristics of normal human epidermis, including AF formation (Gache et al. 2004). Correction of spontaneous homozygous mutations was then shown in two canines with DEB. Neither dog experienced adverse immunological events. Although one dog showed continued expression of $\mathrm{C} 7$, the other did not have as effective a transduction, which resulted in blistering and graft loss after 5 mo (Gache et al. 2011).

An alternative approach to grafting is gene transfer via injection. Woodley et al. injected a lentiviral vector expressing C7 into DEB skin grafted onto immunocompromised mice, producing C7 expression and AF formation. Each injection provided $\mathrm{C} 7$ at the basement membrane for 3 mo (Woodley et al. 2004b). Also using a lentiviral vector, they showed that corrected fibroblasts can be injected intradermally to restore $\mathrm{C} 7$ expression at the basement membrane (Woodley et al. 2003).

Several groups have attempted to bypass pathogenic mutations to reverse the DEB phenotype. Using antisense oligoribonucleotide (AON) therapy, Goto et al. induced "skipping" of a specific exon whose mutation creates a premature termination codon. Skipping this exon resulted in the restoration of the open reading frame. After synthesizing the AON, it was injected into DEB keratinocytes with exon 70 mutations. A small number of these keratinocytes produced C7 and formed anchoring fibrils. Injection into rats grafted with DEB KCs and fibroblasts induced low amounts of C7 expression. Unfortunately, $\mathrm{AON}$ is degraded easily in cells, so therapeutic effects would be short lived (Goto et al. 2006b).

Another approach for RDEB keratinocyte correction is to use trans-splicing to reduce the size of the exogenous COL7A1 transgene. Transsplicing uses the cell's spliceosome to recombine endogenous target pre-mRNA and an exogenous RNA molecule, which replaces part of the target pre-mRNA. However, this approach is mutation specific. Murauer et al. (2011) performed retroviral transduction of RDEB kerati- nocytes with a $3^{\prime}$ pre-trans-splicing molecule, which resulted in expression of C7 at the basement membrane as well as the formation of structures similar to AFs in vitro.

Although it is thought that keratinocytes are responsible for the majority of $\mathrm{C} 7$ production (Regauer et al. 1990), there is debate as to whether keratinocytes or fibroblasts are the best target for DEB gene therapy. After transducing both RDEB keratinocytes and fibroblasts (Chen et al. 2002), Woodley et al. showed that lentiviral-corrected RDEB fibroblasts could be used to create a skin equivalent to normal C7 expression (Woodley et al. 2004a). In another study, retroviral gene transfer was performed, creating skin grafts from DEB fibroblasts and keratinocytes. Transduced fibroblasts had more C7 in the dermal-epidermal junction than transduced keratinocytes (Goto et al. 2006a).

Recently, Osborn et al. (2013) have had success using a novel genome editing tool, TALENs, to correct a specific mutation in RDEB fibroblasts. These particular corrected fibroblasts were then reprogrammed into inducible pluripotent stem cells that showed normal C7 expression and deposition in a teratoma mouse model. In addition to on-target correction of the mutations, three off-target editing events were documented highlighting the necessity of establishing a safety profile of such an in situ approach.

\section{Junctional Epidermolysis Bullosa (JEB)}

In 2006, Mavilio et al. (2006) published a report of successful ex vivo correction of LAMB3 gene using autologous skin grafts for a subject with nonlethal JEB using MLV retrovirus. Nine epidermal sheets were grafted onto wounded areas of the patient's lower extremities. Normal levels of laminin-332 (previously known as laminin 5) were produced in the grafted areas for up to 1 year. Bands specific to the vector size were seen in each of the follow-up biopsies, indicating the proliferation of transduced keratinocytes. No blisters, infection, immune response, or inflammation were observed (Mavilio et al. 2006).

Using a model of lethal Herlitz JEB mice with homozygous LAMB3 mutations, Endo 
et al. (2012) attempted to perform in utero gene transfer. A lentiviral vector encoding for LAMB3 was injected into the amniotic space. Laminin-332 was incorporated into the basement membrane of the skin and the oral mucosa. Although none of the mice survived more than $48 \mathrm{~h}$, harvested transduced skin showed correct expression of laminin-332 for the 6 mo duration of the experiment (Endo et al. 2012).

Similar to the approach used by Murauer et al. (2011) for RDEB, Dallinger et al. (2003) used a system to splice out specific mutant exons (spliceosome-mediated RNA trans-splicing, SMarT) to show correction of a particular collagen 17 mutation in nonlethal JEB keratinocytes in vitro.

\section{Epidermolysis Bullosa Simplex (EBS)}

An AAV gene-targeting vector with promoter trap design targeting was used to correct the KRT14 gene in EBS KCs. Fully functional epidermis was seen for $20 \mathrm{wk}$ postgrafting onto SCID mice (Petek et al. 2010).

As most patients with EBS have heterozygous dominant negative mutations, the defective protein must first be removed before the correct protein can be restored. As such, short inhibitory RNAs (siRNAs) and SMarTare being investigated as methods for disease correction for EBS (Wally et al. 2010; Bowden 2011; Chamcheu et al. 2012).

\section{Pachyonychia Congenita}

Pachyonychia congenita is another dominant negative disease stemming from a keratin mutation resulting in painful plantar keratoderma. In 2010, a double-blind phase-1b study using siRNA was performed on one subject for $17 \mathrm{wk}$. One foot was treated with siRNA injection, the other with a vehicle injection. Regression of the callus and decreased tenderness were seen on the siRNA treated foot, but not the vehicle foot. The changes seen in the treated foot began to revert to their baseline characteristics after the last dose. Unfortunately, the subject experienced intense pain at the injection site. No other adverse events were reported (Leachman et al. 2010).

\section{Melanoma}

There are currently multiple clinical trials of gene therapy for melanoma. One study treated melanoma patients with autologous genetically modified lymphocytes expressing the cancer germ line gene MAGE-A3. Three out of 10 patients showed an increase in circulating antiMAGE-A3 T cells, indicating a possible clinical benefit. No toxicity or adverse side effects were observed (Fontana et al. 2009).

A phase-I/-II study of an interleukin-2 (IL2) intralesional injection mediated by adenovirus shows promise as a treatment for metastatic melanoma and other advanced solid tumors. IL-2 stimulates T-cell proliferation and induces metastatic tumor regression. Two subjects $(n=$ 17) showed complete response, and six showed local responses. The most common side effects were flu-like symptoms and reactions at the injection site (Dummer et al. 2008).

There have also been several clinical trials using genetically engineered autologous $\mathrm{T}$ cells that express T-cell receptors against specific tumor antigens after retroviral transduction. In a study using the NY-ESO-1 antigen to treat metastatic melanoma as well as metastatic synovial cell sarcoma, clinical responses were seen in 5/ 11 melanoma patients and 4/6 synovial sarcoma patients. Notably, two melanoma patients had complete regression for at least 1 year (Robbins et al. 2011). Other metastatic melanoma trials used T-cell receptors to a different antigen, MART-1, and showed tumor regression in 2/13 patients (Morgan et al. 2006) and 6/20 patients (Johnson et al. 2009). Engineered T-cell receptors to gp100 antigen showed a clinical response in 3/16 patients (Johnson et al. 2009).

\section{Ichthyosis}

\section{Lamellar Ichthyosis (LI)}

Patients with lamellar ichthyosis (LI) have a defective barrier and abnormal differentiation of the epidermis because of a transglutaminase 1 deficiency. In an effort to correct the disease phenotype, LI patient keratinocytes were transduced with a retroviral vector engineered to express transglutaminase 1 . Corrected keratino- 
E. Gorell et al.

cytes were grafted on to immunodeficient mice, displaying normal phenotypes (Choate et al. 1996; Khavari et al. 2002).

\section{Harlequin Ichthyosis (HI)}

The gene ABCA12 is important for lipid secretion from lamellar granules; mutations in this gene result in harlequin ichthyosis (HI), which is often lethal. Corrective gene transfer was performed on keratinocytes from HI patients using a cytomegalovirus-based vector in vitro, which restored lamellar granule lipid secretion (Akiyama et al. 2005).

\section{Sjögren-Larsson Syndrome (SLS)}

Sjögren-Larsson syndrome (SLS) is a disorder caused by a mutation in the gene ALDH3A2, which codes for fatty aldehyde dehydrogenase (FALDH). This enzyme catalyzes the oxidation of fatty alcohols into fatty acids. Mutations in ALDH3A2 result in ichthyosis as well as mental retardation and spasticity (which can lead to quadraplegia). Using a recombinant AAV2 vector, FALDH was transduced into SLS keratinocytes. Corrected keratinocytes appeared phenotypically normal with normal FALDH expression (Haug and Braun Falco 2005).

\section{Xeroderma Pigmentosum (XP)}

Xeroderma pigmentosum (XP) results from a defective DNA repair mechanism involving nucleotide excision repair (NER). Cells without a functioning NER develop increased UV-induced damage, increasing mutagenesis and skin cancer development. Current therapy is limited to surgical tumor resection and recommendations to avoid sunlight (Cleaver et al. 2009).

Researchers used a MLV-derived retrovirus to correct the NER mechanism in keratinocytes for one XP subtype. When exposed to UV irradiation, the corrected keratinocytes continued to correctly repair DNA with UV exposed cell survival comparable to wild-type keratinocytes. Corrected keratinocyte holoclones also appeared to convey long-term repair (140 population doublings in this study) while retaining their DNA-repairing abilities (Warrick et al. 2012). Previous attempts at gene therapy for XP were aimed at adenovirus-mediated fibroblast transduction (Marchetto et al. 2004).

\section{Wound Healing}

Wound healing is a complex mechanism characterized by the sequence of inflammation (mediated in part by epidermal growth factor [EGF], platelet derived growth factor [PDGF], and transforming growth factor $\beta$ [TGF- $\beta]$ ) followed by cell proliferation (assisted by PDGF and TGF- $\beta$ ) and angiogenesis (controlled by vascular endothelial growth factor [VEGF] and fibroblast growth factor [FGF]) and then re-epithelialization (via EGF, TGF- $\beta$, PDGF, and FGF) (Barrientos et al. 2008). The mechanism of impaired wound healing is often multifactorial: decreased levels of growth factors or growth factor receptors, defective function of dermal fibroblasts, or damaged nitric oxide synthetase (Khavari et al. 2002).

Gene therapy for wound healing is designed to boost factors that are known to assist with the wound-healing process. Topically applied growth factors are easily degraded and therefore have transient effects. It is also difficult for growth factors to properly penetrate the wound bed and they may be unable to reach their target cells (Galeano et al. 2003; Margolis et al. 2009).

Diabetic mice who received an AAV expressing VEGF-A had increased VEGF-A expression and subsequently improved wound healing, via increased angiogenesis, re-epithelialization, as well as synthesis and maturation of the extracellular matrix, when compared with mice who received an AAV-LacZ control (Galeano et al. 2003). Diabetic mice receiving AAV-VEGF also had increased collagen deposits and a faster time to healing (Brem et al. 2009). Using a nonviral method, VEGF was encoded in minicircle plasmid DNA in combination with a cationic dendrimer then injected subcutaneously into murine diabetic wounds, resulting in high levels of VEGF expression and complete wound healing within 6 days (Kwon et al. 2012). Using a biodegradable cationic polymer, Sonic Hedge- 
hog gene (which activates the angiogenic signaling pathway, including VEGF) was delivered intradermally in murine full-thickness wounds. Expression of VEGF and the chemokine stromal cell derived factor $1 \alpha$ were significantly increased, resulting in accelerated wound closure (Park et al. 2012). Administration of minicircleVEGF165 followed by insonication at $1 \mathrm{MHz}$ showed reasonable wound closure and restored diabetic wound microarchitectures to their normal state (Yoon et al. 2009).

Ko et al. (2011) compared EGF and VEGF gene therapy techniques in a diabetic mouse model using a minigene to deliver VEGF and a plasmid to deliver EGF. Both groups had accelerated wound healing when compared with control diabetic mice. Better blood flow was seen in the VEGF group; however, wound-healing rates were increased in the EGF group, although the results were not statistically significant.

A phase-1 clinical study of periwound injection of an adenovirus encoding PDGFB showed a decrease in the size of chronic venous leg ulcers within 1 month in $14 / 15$ subjects (mean change $=45.2 \%$ decrease).

No adverse events were considered related to the study treatment (Margolis et al. 2009).

Studies have focused on other growth factors as well. Keratinocytes treated with a plasmid encoding for EGF showed increased wound healing when compared with nontreated keratinocytes in a porcine model (Vranckx et al. 2007). When diabetic mice were intradermally injected with a plasmid encoding TGF- $\beta 1$, they experienced an increased rate of cell proliferation, a more organized extracellular matrix, and faster wound closure compared with control groups (Chesnoy et al. 2003). Nonviral gene transfer of insulin-like growth factor-1 (IGF-1), a growth factor that is reduced in diabetic ulcers, into the wounds of diabetic pigs resulted in significantly improved wound healing (Hirsch et al. 2008).

\section{Netherton Syndrome}

Netherton syndrome is a genetic skin disorder in which mutations of the SPINK5 gene result in loss of a serine protease inhibitor LEKTI. This results in premature corneodesmosome degradation and defective keratinization. Di et al. created a SIN lentiviral vector encoding for SPINK5. Transduced keratinocytes showed correction of LEKTI expression in vitro as well as in a murine/ human skin graft model (Di et al.2011). Another group used an AAV2-mediated viral vector to restore LEKTI in NS keratinocytes. Expression of SPINK5 after transduction was increased to approximately $75 \%$ of wild-type KCs (Roedl et al. 2011).

\section{CONCLUDING REMARKS}

Future optimization of both vector design and administration strategies should help to make gene therapy available clinically. Challenges include increasing the effectiveness and durability of cutaneous nonviral vectors and improvement of viral vehicle safety, mainly associated with genomic integration and immune response. As it can be easily monitored for adverse effects, the skin represents a promising organ to explore these possibilities.

The process of commencing a human gene therapy trial is extremely detailed and specific. As with any clinical trial in the United States, all activities must be approved by the FDA as well as an Institutional Review Board (Gorell et al. 2011). In addition to FDA review, human gene transfer research proposals must also be reviewed and approved by the Recombinant DNA Advisory Committee (O'Reilly et al. 2012). Biosafety safeguards must also be followed, which are usually supervised by an Institutional Biosafety Committee in an academic environment. Despite these difficulties, new gene transfer trials are constantly being developed and currently there is a gene therapy drug approved by the European Medicines Agency (the European regulatory agency) for treating lipoprotein lipase deficiency (Moran 2012).

\section{ACKNOWLEDGMENTS}

The authors thank the National Institute of Arthritis and Musculoskeletal and Skin Diseases and the National Institute of Health (Grant 
E. Gorell et al.

No. R01 AR055914), the California Institute for Regenerative Medicine (Grant No. DR1-01454), and the Epidermolysis Bullosa Medical Research Foundation for funding. The authors also thank Mark Yamaguma for assistance with image formatting.

\section{REFERENCES}

Akiyama M, Sugiyama-Nakagiri Y, Sakai K, McMillan JR, Goto M, Arita K, Tsuji-Abe Y, Tabata N, Matsuoka K, Sasaki R, et al. 2005. Mutations in lipid transporter ABCA12 in harlequin ichthyosis and functional recovery by corrective gene transfer. J Clin Invest 115: 1777.

Al Aboud K, Al Hawsawi K, Ramesh V. 2003. Kindler syndrome: Two additional features. Dermatol Online J 9: 20.

Almaani N, Nagy N, Liu L, Dopping-Hepenstal PJ, LaiCheong JE, Clements SE, Techanukul T, Tanaka A, Mellerio JE, McGrath JA. 2010. Revertant mosaicism in recessive dystrophic epidermolysis bullosa. J Invest Dermatol 130: 1937-1940.

Barrientos S, Stojadinovic O, Golinko MS, Brem H, TomicCanic M. 2008. Perspective article: Growth factors and cytokines in wound healing. Wound Repair Regen 16: 585-601.

Bell E, Ehrlich HP, Buttle DJ, Nakatsuji T. 1981. Living tissue formed in vitro and accepted as skin-equivalent tissue of full thickness. Science 211: 1052-1054.

Bowden PE. 2011. Gene therapy for keratin genodermatoses: Striving forward but obstacles persist. J Invest Dermatol 131: 1403-1405.

Boztug K, Schmidt M, Schwarzer A, Banerjee PP, Díez IA, Dewey RA, Böhm M, Nowrouzi A, Ball CR, Glimm H, et al. 2010. Stem-cell gene therapy for the Wiskott-Aldrich syndrome. N Engl J Med 363: 1918-1927.

Braun-Falco M, Doenecke A, Smola H, Hallek M. 1999. Efficient gene transfer into human keratinocytes with recombinant adeno-associated virus vectors. Gene Ther 6: $432-441$.

Brem H, Kodra A, Golinko M, Entero H, Stojadinovic O, Wang V, Sheahan C, Weinberg A, Woo SLC, Ehrlich HP, et al. 2009. Mechanism of sustained release of vascular endothelial growth factor in accelerating experimental diabetic healing. J Invest Dermatol 129: 2275-2287.

Burke JF, Yannas IV, Quinby WC, Bondoc CC, Jung WK. 1981. Successful use of a physiologically acceptable artificial skin in the treatment of extensive burn injury. Ann Surg 194: 413-428.

Cavazzana-Calvo M, Hacein-Bey S, de Saint Basile G, Gross F, Yvon E, Nusbaum P, Selz F, Hue C, Certain S, Casanova JL, et al. 2000. Gene therapy of human severe combined immunodeficiency (SCID)-X1 disease. Science 288: 669672.

Chamcheu JC, Wood GS, Siddiqui IA, Syed DN, Adhami VM, Teng JM, Mukhtar H. 2012. Progress towards genetic and pharmacological therapies for keratin genodermatoses: Current perspective and future promise. Exp Dermatol 21: 481-489.
Chen Z. 2003. Minicircle DNA vectors devoid of bacterial DNA result in persistent and high-level transgene expression in vivo. Mol Ther 8: 495-500.

Chen M, Kasahara N, Keene DR, Chan L, Hoeffler WK, Finlay D, Barcova M, Cannon PM, Mazurek C, Woodley DT. 2002. Restoration of type VII collagen expression and function in dystrophic epidermolysis bullosa. Nat Genet 32: $670-675$.

Chesnoy S, Lee P-Y, Huang L. 2003. Intradermal injection of transforming growth factor- $\beta 1$ gene enhances wound healing in genetically diabetic mice. Pharm Res 20: 345-350.

Choate KA, Medalie DA, Morgan JR, Khavari PA. 1996. Corrective gene transfer in the human skin disorder lamellar ichthyosis. Nat Med 2: 1263-1267.

Choate KA, Lu Y, Zhou J, Choi M, Elias PM, Farhi A, Nelson-Williams C, Crumrine D, Williams ML, Nopper AJ et al. 2010. Mitotic recombination in patients with ichthyosis causes reversion of dominant mutations in KRT10. Science 330: 94-97.

Cleaver J, Lam E, Revet I. 2009. Disorders of nucleotide excision repair: The genetic and molecular basis of heterogeneity. Nat Rev Genet 10: 756-768.

Cooray S, Howe SJ, Thrasher AJ. 2012. Retrovirus and lentivirus vector design and methods of cell conditioning. Methods Enzymol 507: 29-57.

Dallinger G, Puttaraju M, Mitchell LG, Yancey KB, Yee C, Klausegger A, Hintner H, Bauer JW. 2003. Development of spliceosome-mediated RNA trans-splicing (SMaRT) for the correction of inherited skin diseases. Exp Dermatol 12: 37-46.

Dang N, Murrell DF. 2008. Mutation analysis and characterization of COL7A1 mutations in dystrophic epidermolysis bullosa. Exp Dermatol 17: 553-568.

Darquet AM, Cameron B, Wils P, Scherman D, Crouzet J. 1997. A new DNA vehicle for nonviral gene delivery: Supercoiled minicircle. Gene Ther 4: 1341-1349.

Dean HJ, Chen D. 2004. Epidermal powder immunization against influenza. Vaccine 23: 681-686.

de Gruijl TD, van de Ven R. 2012. Chapter six-Adenovirusbased immunotherapy of cancer: Promises to keep. In Advances in cancer research (ed. Curiel DT, Fisher PB), Vol. 115, pp. 147-220. Academic, San Diego, 2012.

De Luca M, Pellegrini G, Mavilio F. 2009. Gene therapy of inherited skin adhesion disorders: A critical overview. $\mathrm{Br}$ J Dermatol 161: 19-24.

Di W-L, Larcher F, Semenova E, Talbot GE, Harper JI, Del Rio M, Thrasher AJ, Qasim W. 2011. Ex-vivo gene therapy restores LEKTI activity and corrects the architecture of netherton syndrome-derived skin grafts. Mol Ther 19: 408-416.

Ditto AJ, Shah PN, Yun YH. 2009. Non-viral gene delivery using nanoparticles. Exp Opin Drug Deliv 6: 1149-1160.

Dormond E, Kamen AA. 2011. Manufacturing of adenovirus vectors: Production and purification of helper dependent adenovirus. Methods Mol Biol 737: 139-156.

Dull T, Zufferey R, Kelly M, Mandel RJ, Nguyen M, Trono D, Naldini L. 1998. A third-generation lentivirus vector with a conditional packaging system. J Virol 72: 8463-8471.

Dummer R, Rochlitz C, Velu T, Acres B, Limacher J-M, Bleuzen P, Lacoste G, Slos P, Romero P, Urosevic M. 
2008. Intralesional adenovirus-mediated interleukin-2 gene transfer for advanced solid cancers and melanoma. Mol Ther 16: $985-994$.

Edelstein ML, Abedi MR, Wixon J. 2007. Gene therapy clinical trials worldwide to 2007-An update. J Gene Med 9: 833-842.

Endo M, Zoltick PW, Radu A, Qiujie J, Matsui C, Marinkovich PM, McGrath J, Tamai K, Uitto J, Flake AW. 2012. Early intra-amniotic gene transfer using lentiviral vector improves skin blistering phenotype in a murine model of Herlitz junctional epidermolysis bullosa. Gene Ther 19: 561-569.

Fan H, Lin Q, Morrissey GR, Khavari PA. 1999. Immunization via hair follicles by topical application of naked DNA to normal skin. Nat Biotechnol 17: 870-872.

Fine JD, Eady RA, Bauer EA, Briggaman RA, Bruckner-Tuderman L, Christiano A, Heagerty A, Hintner H, Jonkman MF, McGrath J, et al. 2000. Revised classification system for inherited epidermolysis bullosa: Report of the Second International Consensus Meeting on Diagnosis and Classification of Epidermolysis Bullosa. J Am Acad Dermatol 42: 1051-1066.

Fontana R, Bregni M, Cipponi A, Raccosta L, Rainelli C, Maggioni D, Lunghi F, Ciceri F, Mukenge S, Doglioni C, et al. 2009. Peripheral blood lymphocytes genetically modified to express the self/tumor antigen MAGE-A3 induce antitumor immune responses in cancer patients. Blood 113: 1651-1660.

Gache Y, Baldeschi C, Del Rio M, Gagnoux-Palacios L, Larcher F, Lacour JP, Meneguzzi G. 2004. Construction of skin equivalents for gene therapy of recessive dystrophic epidermolysis bullosa. Hum Gene Ther 15: 921-933.

Gache Y, Pin D, Gagnoux-Palacios L, Carozzo C, Meneguzzi G. 2011. Correction of dog dystrophic epidermolysis bullosa by transplantation of genetically modified epidermal autografts. J Invest Dermatol 131: 2069-2078.

Gagnoux-Palacios L, Hervouet C, Spirito F, Roques S, Mezzina M, Danos O, Meneguzzi G. 2005. Assessment of optimal transduction of primary human skin keratinocytes by viral vectors. J Gene Med 7: 1178-1186.

Galeano M, Deodato B, Altavilla D, Cucinotta D, Arsic N, Marini H, Torre V, Giacca M, Squadrito F. 2003. Adenoassociated viral vector-mediated human vascular endothelial growth factor gene transfer stimulates angiogenesis and wound healing in the genetically diabetic mouse. Diabetologia 46: 546-555.

Ginn SL, Alexander IE, Edelstein ML, Abedi MR, Wixon J. 2013. Gene therapy clinical trials worldwide to 2012-An update. J Gene Med 15: 65-77.

Gorell ES, Tichy AL, Lane AT. 2011. Successful investigational new drug preparation without reinventing the wheel. $J$ Invest Dermatol 131: 996-998.

Goto M, Sawamura D, Ito K, Abe M, Nishie W, Sakai K, Shibaki A, Akiyama M, Shimizu H. 2006a. Fibroblasts show more potential as target cells than keratinocytes in COL7A1 gene therapy of dystrophic epidermolysis bullosa. J Invest Dermatol 126: 766-772.

Goto M, Sawamura D, Nishie W, Sakai K, McMillan JR, Akiyama M, Shimizu H. 2006b. Targeted skipping of a single exon harboring a premature termination codon mutation: Implications and potential for gene correction therapy for selective dystrophic epidermolysis bullosa patients. J Invest Dermatol 126: 2614-2620.

Green H, Kehinde O, Thomas J. 1979. Growth of cultured human epidermal cells into multiple epithelia suitable for grafting. Proc Natl Acad Sci 76: 5665-5668.

Hacein-Bey-Abina S, Le Deist F, Carlier F, Bouneaud C, Hue C, De Villartay JP, Thrasher AJ, Wulffraat N, Sorensen R, Dupuis-Girod S, et al. 2002. Sustained correction of Xlinked severe combined immunodeficiency by ex vivo gene therapy. N Engl J Med 346: 1185-1193.

Hacein-Bey-Abina S, Garrigue A, Wang GP, Soulier J, Lim A, Morillon E, Clappier E, Caccavelli L, Delabesse E, Beldjord $\mathrm{K}$, et al. 2008. Insertional oncogenesis in 4 patients after retrovirus-mediated gene therapy of SCID-X1. J Clin Invest 118: 3132-3142.

Has C, Spartà G, Kiritsi D, Weibel L, Moeller A, Vega-Warner V, Waters A, He Y, Anikster Y, Esser P, et al. 2012. Integrin $\alpha 3$ mutations with kidney, lung, and skin disease. N Engl J Med 366: 1508-1514.

Haug S, Braun Falco M. 2005. Adeno-associated virus vectors are able to restore fatty aldehyde dehydrogenase-deficiency. Implications for gene therapy in Sjogren-Larsson syndrome. Arch Dermatol Res 296: 568-572.

Hengge UR, Mirmohammadsadegh A. 2000. Adeno-associated virus expresses transgenes in hair follicles and epidermis. Mol Ther 2: 188-194.

Hengge UR, Chan EF, Foster RA, Walker PS, Vogel JC. 1995. Cytokine gene expression in epidermis with biological effects following injection of naked DNA. Nat Genet 10: $161-166$.

Hirsch T, von Peter S, Dubin G, Mittler D, Jacobsen F, Lehnhardt M, Eriksson E, Steinau H-U, Steinstraesser L. 2006. Adenoviral gene delivery to primary human cutaneous cells and burn wounds. Mol Med 12: 199-207.

Hirsch T, Spielmann M, Velander P, Zuhaili B, Bleiziffer O, Fossum M, Steinstraesser L, Yao F, Eriksson E. 2008. Insulin-like growth factor-1 gene therapy and cell transplantation in diabetic wounds. J Gene Med 10: 12471252.

Howe SJ, Mansour MR, Schwarzwaelder K, Bartholomae C, Hubank M, Kempski H, Brugman MH, Pike-Overzet K, Chatters SJ, de Ridder D, et al. 2008. Insertional mutagenesis combined with acquired somatic mutations causes leukemogenesis following gene therapy of SCID-X1 patients. J Clin Invest 118: 3143-3150.

Johnson LA, Morgan RA, Dudley ME, Cassard L, Yang JC, Hughes MS, Kammula US, Royal RE, Sherry RM, Wunderlich JR, et al. 2009. Gene therapy with human and mouse T-cell receptors mediates cancer regression and targets normal tissues expressing cognate antigen. Blood 114: $535-546$

Kardos TJ, Rabussay DP. 2012. Contactless magneto-permeabilization for intracellular plasmid DNA delivery invivo. Hum Vaccin Immunother 8: 1707-1713.

Kay MA. 2011. State-of-the-art gene-based therapies: The road ahead. Nat Rev Genet 12: 316-328.

Khavari PA, Rollman O, Vahlquist A. 2002. Cutaneous gene transfer for skin and systemic diseases. J Intern Med 252: $1-10$. 
E. Gorell et al.

Kim Y-C, Prausnitz MR. 2011. Enabling skin vaccination using new delivery technologies. Drug Deliv Transl Res 1: 7-12.

Ko J, Jun H, Chung H, Yoon C, Kim T, Kwon M, Lee S, Jung S, Kim M, Park J. 2011. Comparison of EGF with VEGF non-viral gene therapy for cutaneous wound healing of streptozotocin diabetic mice. Diabetes Metab J 35: 226235.

Kommareddy S, Baudner BC, Oh S, Kwon SY, Singh M, O'Hagan DT. 2012. Dissolvable microneedle patches for the delivery of cell-culture-derived influenza vaccine antigens. J Pharm Sci 101: 1021-1027.

Korge BP, Krieg T. 1996. The molecular basis for inherited bullous diseases. J Mol Med 74: 59-70.

Kwon MJ, An S, Choi S, Nam K, Jung HS, Yoon CS, Ko JH, Jun HJ, Kim TK, Jung SJ, et al. 2012. Effective healing of diabetic skin wounds by using nonviral gene therapy based on minicircle vascular endothelial growth factor DNA and a cationic dendrimer. J Gene Med 14: 272-278.

Lai-Cheong JE, McGrath JA, Uitto J. 2011. Revertant mosaicism in skin: Natural gene therapy. Trends Mol Med 17: $140-148$.

Larcher F, Dellambra E, Rico L, Bondanza S, Murillas R, Cattoglio C, Mavilio F, Jorcano JL, Zambruno G, Del Rio M. 2007. Long-term engraftment of single genetically modified human epidermal holoclones enables safety pre-assessment of cutaneous gene therapy. Mol Ther 15: $1670-1676$.

Leachman S, Hickerson R, Schwartz M, Bullough E, Hutcherson S, Boucher K, Hansen CD, Eliason M, Srivatsa GS Kornbrust D, et al. 2010. First-in-human mutation-targeted siRNA phase Ib trial of an inherited skin disorder. Mol Ther 18: 442-446.

Mali P, Yang L, Esvelt KM, Aach J, Guell M, DiCarlo JE, Norville JE, Church GM. 2013. RNA-Guided Human Genome Engineering via Cas9. Science 339: 823-826.

Marchetto MCN, Muotri A, Burns D, Friedberg E, Menck CFM. 2004. Gene transduction in skin cells: Preventing cancer in xeroderma pigmentosum mice. Proc Natl Acad Sci 101: 17759-17764.

Margolis D, Morris L, Papadopoulos M, Weinberg L, Filip J, Lang S, Vaikunth S, Crombleholme T. 2009. Phase I study of H5.020CMV.PDGF- $\beta$ to treat venous leg ulcer disease. Mol Ther 17: 1822-1829.

Marinkovich MP. 1993. The molecular genetics of basement membrane diseases. Arch Dermatol 129: 1557-1565.

Marinkovich MP. 2012. Inherited epidermolysis bullosa. In Fitzpatrick's dermatology in general medicine (ed. Goldsmith LA, et al.), pp. 649-665. McGraw Hill, New York.

Mavilio F, Pellegrini G, Ferrari S, Di Nunzio F, Di Iorio E, Recchia A, Maruggi G, Ferrari G, Provasi E, Bonini C, et al. 2006. Correction of junctional epidermolysis bullosa by transplantation of genetically modified epidermal stem cells. Nat Med 12: 1397-1402.

Miller AD. 1992. Retroviral vectors. Curr Topic Microbiol Immunol 158: 1-24.

Miller DL, Pislaru SV, Greenleaf JE. 2002. Sonoporation: Mechanical DNA delivery by ultrasonic cavitation. Somat Cell Mol Genet 27: 115-134.

Mohammed AJ, AlAwaidy S, Bawikar S, Kurup PJ, Elamir E, Shaban MMA, Sharif SM, van der Avoort HGAM, Pal- lansch MA, Malankar P, et al. 2010. Fractional doses of inactivated poliovirus vaccine in Oman. $N$ Engl $\mathrm{J} \mathrm{Med}$ 362: $2351-2359$.

Moran N. 2012. First gene therapy nears landmark European market authorization. Nat Biotechnol 30: 807-809.

Morgan RA, Dudley ME, Wunderlich JR, Hughes MS, Yang JC, Sherry RM, Royal RE, Topalian SL, Kammula US, Restifo NP, et al. 2006. Cancer regression in patients after transfer of genetically engineered lymphocytes. Science 314: $126-129$.

Murauer EM, Gache Y, Gratz IK, Klausegger A, Muss W, Gruber C, Meneguzzi G, Hintner H, Bauer JW. 2011. Functional correction of type VII collagen expression in dystrophic epidermolysis bullosa. J Invest Dermatol 131: $74-83$.

O’Reilly M, Shipp A, Rosenthal E, Jambou R, Shih T, Montgomery M, Gargiulo L, Patterson A, Corrigan-Curay J. 2012. NIH oversight of human gene transfer research involving retroviral, lentiviral, and adeno-associated virus vectors and the role of the NIH recombinant DNA advisory committee. Methods Enzymol 507: 313-335.

Ortiz-Urda S, Thyagarajan B, Keene DR, Lin Q, Fang M, Calos MP, Khavari PA. 2002. Stable nonviral genetic correction of inherited human skin disease. Nat Med 8: 1166-1170.

Ortiz-Urda S, Lin Q, Green C, Keene D, Marinkovich MP, Khavari P. 2003. Injection of genetically engineered fibroblasts corrects regenerated human epidermolysis bullosa skin tissue. J Clin Invest 111: 251-255.

Osborn MJ, Starker CG, McElroy AN, Webber BR, Riddle MJ, Xia L, DeFeo AP, Gabriel R, Schmidt M, Von Kalle C, et al. 2013. TALEN-based gene correction for epidermolysis bullosa. Mol Ther 21: 1151-1159.

Pabo CO, Peisach E, Grant RA. 2001. Design and selection of novel CYS2HIS2 zinc finger proteins. Ann Rev Biochem 70: 313-340.

Paller AS. 1996. The genetic basis of hereditary blistering disorders. Curr Opin Pediatr 8: 367-371.

Park H-J, Lee J, Kim M-J, Kang T, Jeong Y, Um S, Cho S-W. 2012. Sonic hedgehog intradermal gene therapy using a biodegradable poly ( $\beta$-amino esters) nanoparticle to enhance wound healing. Biomaterials 33: 9148-9156.

Pasmooij AMG, Jonkman MF. 2012. First symposium on natural gene therapy of the skin. Exp Dermatol 21: 236-239.

Pasmooij AMG, Garcia M, Escamez MJ, Nijenhuis AM, Azon A, Cuadrado-Corrales N, Jonkman MF, Del Rio M. 2010. Revertant mosaicism due to a second-site mutation in COL7A1 in a patient with recessive dystrophic epidermolysis bullosa. J Invest Dermatol 130: 2407-2411.

Pasmooij AMG, Nijenhuis M, Brander R, Jonkman MF. 2012. Natural gene therapy may occur in all patients with generalized non-Herlitz junctional epidermolysis bullosa with COL17A1 mutations. J Invest Dermatol 132: $1374-1383$.

Pearton M, Saller V, Coulman SA, Gateley C, Anstey AV, Zarnitsyn V, Birchall JC. 2012. Microneedle delivery of plasmid DNA to living human skin: Formulation coating, skin insertion and gene expression. J Control Release 160: $561-569$. 
Petek L, Fleckman P, Miller D. 2010. Efficient KRT14 targeting and functional characterization of transplanted human keratinocytes for the treatment of epidermolysis bullosa simplex. Mol Ther 18: 1624-1632.

Porteus MH, Baltimore D. 2003. Chimeric nucleases stimulate gene targeting in human cells. Science 300: 763.

Raghavachari N, Fahl WE. 2002. Targeted gene delivery to skin cells in vivo: A comparative study of liposomes and polymers as delivery vehicles. J Pharm Sci 91: 615-622.

Regauer S, Seiler GR, Barrandon Y, Easley KW, Compton CC. 1990. Epithelial origin of cutaneous anchoring fibrils. J Cell Biol 111: 2109-2115.

Rheinwald JG, Green H. 1975. Serial cultivation of strains of human epidermal keratinocytes: The formation of keratinizing colonies from single cells. Cell 6: 331-343.

Robbins PF, Morgan RA, Feldman SA, Yang JC, Sherry RM, Dudley ME, Wunderlich JR, Nahvi AV, Helman LJ, Mackall CL, et al. 2011. Tumor regression in patients with metastatic synovial cell sarcoma and melanoma using genetically engineered lymphocytes reactive with NYESO-1. J Clin Oncol 29: 917-924.

Roedl D, Oji V, Buters JTM, Behrendt H, Braun-Falco M 2011. rAAV2-mediated restoration of LEKTI in LEKTIdeficient cells from Netherton patients. J Dermatol Sci 61: 194-198.

Siprashvili Z, Nguyen NT, Bezchinsky MY, Marinkovich MP, Lane AT, Khavari PA. 2010. Long-term type VII collagen restoration to human epidermolysis bullosa skin tissue. Human Gene Ther 21: 1299-1310.

Smith FJD, Morley SM, McLean WHI. 2004. Novel mechanism of revertant mosaicism in dowling-meara epidermolysis bullosa simplex. J Investig Dermatol 122: 73-77.

Titomirov AV, Sukharev S, Kistanova E. 1991. In vivo electroporation and stable transformation of skin cells of newborn mice by plasmid DNA. Biochim Biophys Acta 1088: $131-134$.

Tolmachov OE. 2011. Building mosaics of therapeutic plasmid gene vectors. Curr Gene Ther 11: 466-478.

Uitto J, Pulkkinen L. 1996. Molecular complexity of the cutaneous basement membrane zone. Mol Biol Rep 23: $35-46$.

Uitto J, Richard G. 2005. Progress in epidermolysis bullosa: From eponyms to molecular genetic classification. Clin Dermatol 23: 33-40.

Uitto J, Pulkkinen L, Christiano AM. 1994. Molecular basis of the dystrophic and junctional form of epidermolysis bullosa: mutations in the type VII collagen and kalinin (laminin-5) genes. J Invest Dermatol 103: 39S-45S.

van den Akker PC, Nijenhuis M, Meijer G, Hofstra RMW, Jonkman M, Pasmooij AMG. 2012. Natural gene therapy in dystrophic epidermolysis bullosa. Arch Dermatol 148: 213-216.

Vranckx JJ, Hoeller D, Velander PEM, Theopold CFP, Petrie N, Takedo A, Eriksson E, Feng Y. 2007. Cell suspension cultures of allogenic keratinocytes are efficient carriers for ex vivo gene transfer and accelerate the healing of full-thickness skin wounds by overexpression of human epidermal growth factor. Wound Repair Regen 15: 657664.

Wally V, Brunner M, Lettner T, Wagner M, Koller U, Trost A, Murauer EM, Hainzl S, Hintner H, Bauer JW. 2010. K14 mRNA reprogramming for dominant epidermolysis bullosa simplex. Hum Mol Genet 19: 4715-4725.

Wang H, Yang H, Shivalila Chikdu S, Dawlaty Meelad M, Cheng Albert W, Zhang F, Jaenisch R. 2013. One-step generation of mice carrying mutations in multiple genes by CRISPR/Cas-mediated genome engineering. Cell 153: 910-918.

Warrick E, Garcia M, Chagnoleau C, Chevallier O, Bergoglio V, Sartori D, Mavilio F, Angulo JF, Avril M-F, Sarasin A, et al. 2012. Preclinical corrective gene transfer in xeroderma pigmentosum human skin stem cells. Mol Ther 20: 798807.

Williams RS, Johnston SA, Riedy M, DeVit MJ, McElligott SG, Sanford JC. 1991. Introduction of foreign genes into tissues of living mice by DNA-coated microprojectiles. Proc Natl Acad Sci 88: 2726-2730.

Woodley DT, Krueger GG, Jorgensen CM, Fairley JA, Atha T, Huang Y, Chan L, Keene DR, Chen M. 2003. Normal and gene-corrected dystrophic epidermolysis bullosa fibroblasts alone can produce type VII collagen at the basement membrane zone. J Invest Dermatol 121: 1021-1028.

Woodley DT, Keene DR, Atha T, Huang Y, Lipman K, Li W, Chen M. 2004a. Injection of recombinant human type VII collagen restores collagen function in dystrophic epidermolysis bullosa. Nat Med 10: 693-695.

Woodley DT, Keene DR, Atha T, Huang Y, Ram R, Kasahara N, Chen M. 2004b. Intradermal injection of lentiviral vectors corrects regenerated human dystrophic epidermolysis bullosa skin tissue in vivo. Mol Ther 10: 318-326.

Yoon CS, Jung HS, Kwon MJ, Lee SH, Kim CW, Kim MK, Lee M, Park JH. 2009. Sonoporation of the minicircleVEGF $^{165}$ for wound healing of diabetic mice. Pharm Res 26: 794-801.

Zheng D, Giljohann DA, Chen DL, Massich MD, Wang X-Q, Iordanov H, Mirkin CA, Paller AS. 2012. Topical delivery of siRNA-based spherical nucleic acid nanoparticle conjugates for gene regulation. Proc Natl Acad Sci 109: 11975-11980. 


\section{$\&_{\mathrm{CSH}}^{\infty} \&$ Cold Spring Harbor

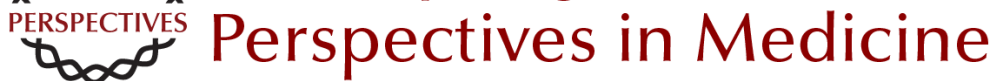

\section{Gene Therapy for Skin Diseases}

Emily Gorell, Ngon Nguyen, Alfred Lane and Zurab Siprashvili

Cold Spring Harb Perspect Med 2014; doi: 10.1101/cshperspect.a015149

Subject Collection The Skin and Its Diseases

Melanoma: Clinical Features and Genomic Insights

Elena B. Hawryluk and Hensin Tsao

Wound Healing and Skin Regeneration

Makoto Takeo, Wendy Lee and Mayumi Ito

The Dermal Papilla: An Instructive Niche for

Epithelial Stem and Progenitor Cells in

Development and Regeneration of the Hair Follicle Bruce A. Morgan

Immunology and Skin in Health and Disease

Jillian M. Richmond and John E. Harris

Desmosomes: Regulators of Cellular Signaling and Adhesion in Epidermal Health and Disease Jodi L. Johnson, Nicole A. Najor and Kathleen J. Green

Markers of Epidermal Stem Cell Subpopulations in Adult Mammalian Skin Kai Kretzschmar and Fiona M. Watt

Psoriasis

Paola Di Meglio, Federica Villanova and Frank O. Nestle

Cell Therapy in Dermatology Gabriela Petrof, Alya Abdul-Wahab and John A. McGrath
Modeling Cutaneous Squamous Carcinoma

Development in the Mouse

Phillips Y. Huang and Allan Balmain

Natural and Sun-Induced Aging of Human Skin Laure Rittié and Gary J. Fisher

Advanced Treatment for Basal Cell Carcinomas Scott X. Atwood, Ramon J. Whitson and Anthony E. Oro

Epidermal Polarity Genes in Health and Disease Frederik Tellkamp, Susanne Vorhagen and Carien M. Niessen

Induced Pluripotent Stem Cells in Dermatology:

Potentials, Advances, and Limitations Ganna Bilousova and Dennis R. Roop

The Genetics of Human Skin Disease Gina M. DeStefano and Angela M. Christiano

p53/p63/p73 in the Epidermis in Health and Disease

Vladimir A. Botchkarev and Elsa R. Flores

Diversification and Specialization of Touch

Receptors in Skin

David M. Owens and Ellen A. Lumpkin

For additional articles in this collection, see http://perspectivesinmedicine.cshlp.org/cgi/collection/ 